\title{
Advection, dispersion and mortality of a patch of southern bluefin tuna larvae Thunnus maccoyii in the East Indian Ocean
}

\author{
T. L. O. Davis ${ }^{1}$, V. Lyne ${ }^{1}$, G. P. Jenkins ${ }^{2}$ \\ ${ }^{1}$ CSIRO Division of Fisheries, Marine Laboratories, GPO Box 1538, Hobart, Tasmania 7001, Australia \\ ${ }^{2}$ Department of Zoology, University of Melbourne, Parkville, Victoria 3052, Australia
}

\begin{abstract}
Mortality rate of southern bluefin tuna larvae Thunnus maccoyii was determined from measurements of a large, high density patch of larvae in the East Indian Ocean made in January-February 1987. An advection-diffusion-mortality model that improves on elliptical spread models was used to model changes in the patch over a period of $6 \mathrm{~d}$. The patch at the start of sampling consisted of a distinct cohort of larvae 7 to $8 \mathrm{~d}$ old. Diffusion in subsequent $2 \mathrm{~d}$ intervals was slow $\left(1.02\right.$ to $\left.1.5 \mathrm{~m}^{2} \mathrm{~s}^{-1}\right)$ but within the bounds observed for patch scales in the order of a few kilometres wide. Intensifying southwesterly winds were opposed by advection with a southwestward drift of about $6 \mathrm{~cm} \mathrm{~s}^{-1}$. The original intention of using a free-drifting drogue to track the centre of the patch, and thereby account for the advective process, was not successful because of the relative drift of buoy and larval patch. Instantaneous mortality $(Z)$ was estimated to be $0.66 \mathrm{~d}^{-1}$ (a daily survival rate of $52 \%$ ). This is the first time the mortality of tuna larvae has been directly estimated in the open ocean.
\end{abstract}

\section{INTRODUCTION}

Southern bluefin tuna Thunnus maccoyii is an important commercial species fished by Australia, Japan, New Zealand and other countries. Adults have an almost circumpolar distribution between latitudes 30 and $50^{\circ} \mathrm{S}$ (Shingu 1981), although the only known spawning ground is south of Java in the East Indian Ocean within the latitudes 7 to $20^{\circ} \mathrm{S}$ and longitudes 102 to $124^{\circ} \mathrm{E}$ (Nishikawa et al. 1985). The species is thought to be substantially overexploited (Caton \& Majkowski 1987). However, little is known of its early life history and nothing is known of the patterns of dispersal and rates of mortality of the larvae, although it is believed that larval mortality is an important component of recruitment variability (Cushing 1975 Rothschild et al. 1989). It is also considered that the most important source of bias in estimating egg production is likely to be mortality during the period from spawning to the stage on which the estimate is based (Saville \& Schnack 1981). As it is not yet possible to identify tuna eggs or larvae $<3.0 \mathrm{~mm}$ (SL) to species (Nishikawa \& Rimmer 1987), surveys to estimate abundance must be based on the larger larvae.

There are no estimates of larval mortality rates for any species of tuna in the open ocean. Tuna larvae are generally thought to occur in low densities and have a patchy distribution (Wade 1951, Strasburg, 1960, Klawe 1963, Richards \& Simmons 1971), and while isolated tows have produced moderately large catches of tuna larvae - presumably because they intersected a patch (Richards \& Potthoff 1980, Yukinawa 1987) patches have not been reported in the literature. During a study to determine the optimal sampling procedure for estimating tuna larval abundance in the Indian Ocean (Davis et al. 1990a, b), we found a large patch of Thunnus maccoyii larvae, which we were able to sample intensively over $6 \mathrm{~d}$. This provided us with an opportunity to study the processes of advection, dispersion and mortality of tuna larvae in the open ocean

In the open ocean, the transport and distortion of larval distributions produced by the physical processes of advection and diffusion must be accounted for before estimates of mortality are possible. Theoretically, population mortality could be estimated by intensively and regularly sampling an isolated patch of larvae and the area to which they could have spread in order to estimate temporal changes in population numbers. In practice, apart from the problem of tracking the patch it is difficult to sample an area that is wide enough, or to 
sample sufficiently intensively, to produce accurate estimates of population sizes and hence mortality (Harding \& Talbot 1973, Henderson et al. 1984, Leak \& Houde 1987, Kiørboe et al. 1988, Chenoweth et al. 1989. Incze et al. 1989). An alternative approach is to examine the successive changes in larval densities, but this requires modelling changes in larval abundance due to the physical processes of advection and diffusion. Fortier \& Leggett (1985) studied the decline in densities of capelin larvae around a free-drifting drogue by assuming that the dilution of larvae, presumed to be primarily due to vertical mixing, was reflected in salinity changes. In an advective-diffusive environment, an isolated larval patch from a single instantaneous spawning would produce a characteristic eliptical spread. Mortality rates have been estimated by forcibly fitting ellipses to observed distributions by statistical regression or optimization (Talbot 1977, Munk et al. 1986, Heath \& MacLachlan 1987, McGurk 1989). In this paper, we present results from a novel method that uses a model of advection, diffusion and mortality to optimize predictions from one period to the next.

\section{MATERIALS AND METHODS}

Field sampling. Sampling was carried out in the southern part of the spawning grounds (Nishikawa et al. 1985) in the North Australia Basin, which has a bottom depth of ca $5000 \mathrm{~m}$ (Fig. 1). The station at $16^{\circ} 30.2^{\prime} \mathrm{S}, 115^{\circ} 50.4^{\prime} \mathrm{E}$ was selected after large numbers of Thunnus maccoyii larvae $\left(>4\right.$ larvae $\mathrm{m}^{-3}$ ) were caught in a trial oblique tow. A satellite-tracked buoy drogued at $20 \mathrm{~m}$ depth with a parachute (Cresswell et

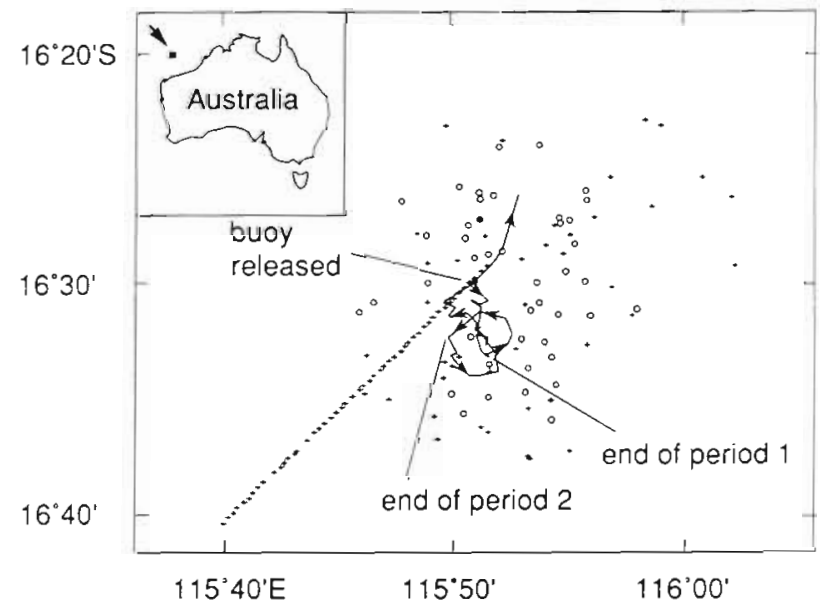

Fig. 1. Ichthyoplankton stations in the Indian Ocean northwest of Australia taken on 28 January to 2 February 1987 (periods 1 to 3). Arrow and line indicate the drift trajectory of satellitetracked buoy no. 6128 during the period of sampling; station locations ( 0 : day, + , night) were chosen randomly to lie within $20 \mathrm{~km}$ of the buoy's position al. 1978) was deployed at this station on 28 January 1987 at $17: 40 \mathrm{~h}$ (local time) to flag the patch of larvae.

The larvae were sampled with a $70 \mathrm{~cm}$ diameter ring net made of plain weave Estal monofilament with a mesh aperture of $0.5 \mathrm{~mm}$ and open area ratio of $5: 1$ (Davis et al. 1989) fitted with a calibrated mechanical General Oceanics flowmeter which was towed at speeds of 1.0 to $1.3 \mathrm{~m} \mathrm{~s}^{-1}$. A transect of surface tows, each about $390 \mathrm{~m}$ long and separated by about $200 \mathrm{~m}$. was made starting $2 \mathrm{~km} \mathrm{NE}$ of the buoy and heading in a SW direction into the wind for $30 \mathrm{~km}$. These were completed at night between 21:05 h on 28 January and 03:09 h on 29 January. The surface tows were deployed from a boom on the port side amidships, clear of the wake of the vessel about $0.5 \mathrm{~m}$ under the surface, oscillating between 0 and $2 \mathrm{~m}$. A total of 88 oblique tows was then made at random positions within a $20 \mathrm{~km}$ radius of the buoy, starting at $08: 40 \mathrm{~h}$ on 29 January and finishing at $23: 30 \mathrm{~h}$ on 2 February. Oblique tows, guided by real-time depth data, were made from the surface to the top of the thermocline (about $50 \mathrm{~m}$ depth) and back to the surface to cover the known depth range of the tuna larvae (Davis et al. 1990a). Ichthyoplankton sampling was not carried out during transitional light periods of dawn and dusk.

The temperature and salinity of the water pumped from about $2 \mathrm{~m}$ depth were recorded continuously by a thermosalinograph (Grundy Environmental Systems Inc. Model no. 6620). Casts were made at random positions to a depth of either 150 or $500 \mathrm{~m}$ at dawn and dusk each day with a Neil Brown Mark 3B CTD probe with a 1150 deck unit and General Oceanics rosette sampler fitted with 81 Niskin bottles. Due to calibration problems with the CTD sensors only the raw temperature-salinity data were obtained. Wind speed measurements were made using the ship's anemometer. Full details of ichthyoplankton and hydrographic data collected on this cruise are presented in Davis \& Clementson (1989).

Treatment of samples. Ichthyoplankton samples were preserved in $95 \%$ ethanol. Tuna larvae were sorted from the plankton using a rotatable sorting ring under a dissecting microscope with dark-field illumination. Thunnus maccoyii were identified using the criteria of Nishikawa (1985) and Nishikawa \& Rimmer (1987). Identification was only attempted on larvae $>3.5 \mathrm{~mm}$ as the diagnostic pattern of melanophore distribution may not have developed in smaller larvae. Some confusion exists in distinguishing between $T$. maccoyii and $T$. obesus either because the dorsal body pigments cannot be detected in some $T$ maccoyii larvae, or, rarely, when $I$ obesus has a caudal fin pigment spot dorsal to the notochord (Nishikawa \& Rimmer 1987). As only one $T$ obesus larvae was identified with the usual pattern of pigment distribution in this study 
confusion of the 2 species was not a problem. Tuna larval densities were expressed as number per $\mathrm{m}^{2}$ sea surface calculated from the volume filtered and the depth reached by the net. The age composition of $T$. maccoyii in each sample along the surface transect was determined from the criteria of Jenkins \& Davis (1990). Where more than 20 larvae were present, a random subsample of 20 larvae was aged. The abundance data were grouped into 3 periods (Table 1). The grouping of stations into ca $2 \mathrm{~d}$ periods was necessary to provide sufficient sampling coverage to define changes in the spatial distribution of $T$. maccoyii larvae with time, although it does not represent a true synoptic pattern. The start of each day was taken as $18: 00 \mathrm{~h}$ to coincide with the approximate onset of daily otolith increment formation (Jenkins \& Davis 1990). Period 1 included data from the surface transect after surface catches (S) were adjusted to oblique tow equivalents $(O)$ using the regression equation $\left(O=0.86 S+29.23, R^{2}=0.83\right.$, $\mathrm{p}<0.001$ ) determined from paired surface and oblique tows taken over the $6 \mathrm{~d}$ period (Davis et al. 1990a). In an attempt to reduce the variation in catches in oblique tows due to day/night differences in avoidance, day catches were divided by the mean day/night catch ratio of 0.27 ( $\mathrm{SE}=0.07$ ) determined from oblique tows taken over the $6 \mathrm{~d}$ period (Davis et al. 1990a). Ichthyoplankton and station data are presented in detail in Davis \& Clementson (1989)

Advection-diffusion-mortality modelling. Parameters for advection-diffusion and mortality are optimized from a model which predicts the evolution of a given initial larval distribution. This involves calculating larval densities corresponding to the initial distribution on a uniform grid encompassing an area larger than the measured distribution. Larval densities at each of the grid points are considered to be seed populations. The predicted concentration at any one of the stations for the next period is obtained by summing the contributions from the seed populations, each of which spreads as an ellipse under the influence of advection, diffusion and mortality. The model makes no assumptions about the nature of the drift of the larvae; whether it is passive or active. It simply fits the parameters to best describe the change in the observed distribution.
The evolution of the larval distribution is described by the standard linear equation for advection, diffusion and mortality:

$$
\frac{\partial N}{\partial t}=K_{x} \frac{\partial^{2} N}{\partial x^{2}}+K_{y} \frac{\partial^{2} N}{\partial y^{2}}-U \frac{\partial N}{\partial x}-V \frac{\partial N}{\partial x}-Z N
$$

where $N=$ larval density (no. $\mathrm{m}^{-2}$ ); $U=$ advection in the east-west direction $(x)$, positive to the east $\left(\mathrm{m} \mathrm{s}^{-1}\right)$; $V=$ advection in the north-south direction $(y)$, positive to the north $\left(\mathrm{m} \mathrm{s}^{-1}\right)_{i} t=$ time $(\mathrm{s})_{i} K_{\mathrm{x}}, K_{y}=$ diffusion coefficients in the $x$ and $y$ directions, respectively $\left(\mathrm{m}^{2} \mathrm{~s}^{-1}\right)$; and $Z=$ instantaneous mortality $\left(\mathrm{s}^{-1}\right)$.

The initial distribution was interpolated onto a uniform grid by computing the weighted average of the densities around the neighborhood of each grid point. A $30 \times 30$ grid with a grid interval of $1.84 \mathrm{~km}$ on the $x$ axis and $1.53 \mathrm{~km}$ on the $y$-axis was centered at the initial distribution. For the interpolation, the search radius in each of the horizontal directions was set at one-tenth of the respective model domain lengths. Inverse distance-squared weighting was used for the interpolation. One difficulty with this modelling approach is the need to assign a time to each of the grid points. This is necessary because it takes at least a day to measure the distributions, and the predicted evolution of the seed populations depends on the time difference between the initial distribution and the observations at the next period. The weighting procedure used for the densities was used to assign an average time to each grid point. Given these times and a set of assumed model parameters, the prediction of density $\left(N_{1}\right)$ at each sampling station (i) for the next period is given by summing the contributions of the seed populations which are instantaneously released at each grid point:

where

$$
\hat{N}_{j}=\sum_{l, k} \tilde{N}_{j, k} g_{j, k} \Delta x \Delta y,
$$

$g_{\jmath, k}=\frac{1}{4 \pi\left(K_{C} K_{l}\right)^{1 / 2} \Delta t} \exp \left[\frac{\left(-x_{c}{ }^{2} / K_{c}-y_{1}{ }^{2} / K_{l}\right)}{4 \Delta t}-Z \Delta t\right]$

and $\tilde{N}_{j, k}=$ larval densities for the first period interpolated onto a grid with $n x$ nodes in the $j$ direction $(\mathrm{E}-\mathrm{W})$ and $n y$ nodes in the $k$ direction $(\mathrm{N}-\mathrm{S})_{i}\left(x_{c}, y_{l}\right)=$ the

Table 1 Details of samples used to estimate the distribution and abundance (no. $\mathrm{m}^{-2}$ ) of Thunnus maccoyii larvae in the 3 time periods. The number of stations sampled during the day or night is indicated by $\mathrm{D}$ or $\mathrm{N}$, respectively. TS: surface tows along the

\begin{tabular}{|c|c|c|c|c|c|c|c|}
\hline Period & $\begin{array}{l}\text { Sampling } \\
\text { method }\end{array}$ & $\begin{array}{c}\text { Start } \\
\text { (local time) }\end{array}$ & $\begin{array}{c}\text { Finish } \\
\text { (local time) }\end{array}$ & $\begin{array}{c}\text { No. } \\
\text { of stations }\end{array}$ & $\begin{array}{l}\text { Maximum } \\
\text { density }\end{array}$ & $\begin{array}{l}\text { Mean } \\
\text { density }\end{array}$ & $\begin{array}{c}\text { Standard } \\
\text { error }\end{array}$ \\
\hline 1 & TS \& random & $21: 05 \mathrm{~h}, 28 \mathrm{Jan}$ & $16: 01 \mathrm{~h}, 30 \mathrm{Jan}$ & $16 \mathrm{D}, 60 \mathrm{~N}$ & 754 & 53.3 & 18.3 \\
\hline 2 & Random & $20: 35 \mathrm{~h}, 30 \mathrm{Jan}$ & $16: 24 \mathrm{~h}, 1 \mathrm{Feb}$ & $20 \mathrm{D}, 20 \mathrm{~N}$ & 64 & 9.0 & 2.3 \\
\hline 3 & Random & $20: 28$ h, $1 \mathrm{Feb}$ & $23: 31 \mathrm{~h}, 2 \mathrm{Feb}$ & $8 \mathrm{D}, 15 \mathrm{~N}$ & 10 & 2.2 & 0.7 \\
\hline
\end{tabular}
transect 
distances $\left(x_{i}-\tilde{x}_{j, k}-U \Delta t\right),\left(y_{1}-\bar{y}_{j, k}-V \Delta t\right)$ rotated into the direction of the principal diffusion axes; $\Delta t=t_{j}-t_{1, k}$ is the time difference between the time of sampling for the next period $\left(t_{j}\right)$ and the time computed at the grid point $\left(t_{1, k}\right): g_{j, k}$ corresponds to the Green's function for advection, dispersion and mortality; and $\Delta x$ and $\Delta y=$ the grid spacing in the $x$ and $y$ directions respectively. A similar but simpler formulation was used by Hill (1990) to examine potential limits to recruitment in Nephrops norvegicus by advection, diffusion and mortality.

The sum of squares error computed from these fitted distributions is used in an optimization procedure (modified Levenberg-Marquardt method subject to simple bounds - routine BCLSF in the IMSL library) to estimate optimal model parameters. Manual guidance and tuning were often required to arrive at satisfactory 'optimal' estimates. The optimization was done in 3 stages. Crude estimates of the advection parameters were first obtained by contouring the measured distributions (by interpolating densities onto a grid and then using the subroutine CONREC from the NCAR suite of programs) and calculating the advection required to shift the centres of the patch from one period to the next. These estimates were optimized whilst keeping the diffusion and mortality parameters fixed at some reasonable value (usually determined a posteriori). The diffusion coefficients and mortality were optimized next whilst keeping the diffusion tensor angle $(\phi)$ fixed at some arbitrary value. The diffusion tensor angle was optimized last. After another iteration of the optimizations, the resulting predictions were contoured and compared with observations to fine tune the parameters.

A similar approach was used to estimate the advection-diffusion parameters from the salinity distributions, but in this case only the deviations from the mean were advected and diffused. The mean value was made equal to the mean calculated from the measured stations for the first period.

\section{RESULTS}

\section{Drift of the satellite buoy}

The buoy drifted initially against the wind, which later intensified from the southwest and, by the end of the third period, had reversed the drift of the buoy (Fig. 2). During period 2 and for much of period 3, the buoy drifted anticlockwise for about 2 cycles before accelerating rapidly to the north at the end of period 3 . The wind increased from $42 \mathrm{~km} \mathrm{~h}^{-1}$ in period 1 to $58 \mathrm{~km} \mathrm{~h}^{-1}$ by the end of period 3. Without knowing how the buoy responded to wind drag. we could not

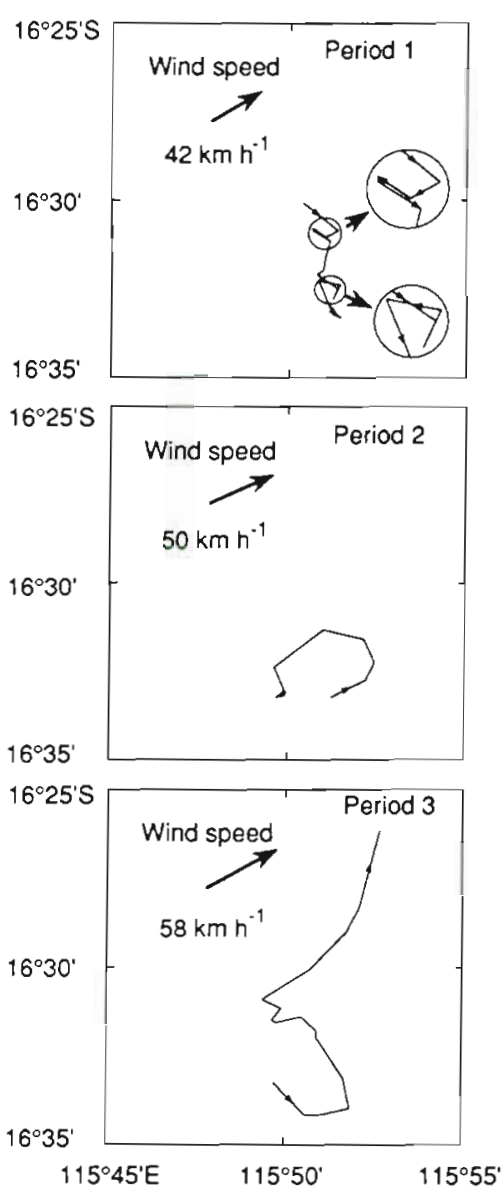

Fig. 2. Wind speed and direction and drift trajectory of the drogue buoy during each sampling period. Arrows indicate the direction to which the wind is blowing and the buoy is drifting

use the buoy track to account for advection of the larvae.

\section{Distribution and abundance of larvae along the transect}

Of the tuna larvae caught in the transect that intersected the patch at the beginning of period $1,43 \%$ were $<3.5 \mathrm{~mm}$ and thus identification was not attempted. As almost all larvae $>3.5 \mathrm{~mm}$ were identified as Thunnus maccoyii 7390 T. maccoyii and 7 T. alalunga larvae), we assumed that the smaller larvae were also $T$ maccoyii. The density of $T$. maccoyii larvae in contiguous stations along the surface transect showed a Gaussian distribution, starting at a peak density of $754 \mathrm{~m}^{-2}$ and declining to $4 \mathrm{~m}^{-2}$ at the 11 th station, a distance of about $6.5 \mathrm{~km}$ (Fig. 3). It can be judged from the shape of the density distribution that the transect probably passed close to the patch centre but traversed no more than the radius of the patch. $T$ maccoyil larvae 
Fig. 3. Thunnus maccoyii. Density of larvae and their age composition in the surface transect starting near the estimated patch centre and extending in a southwest direction. Larval density is plotted on a $\log$ scale
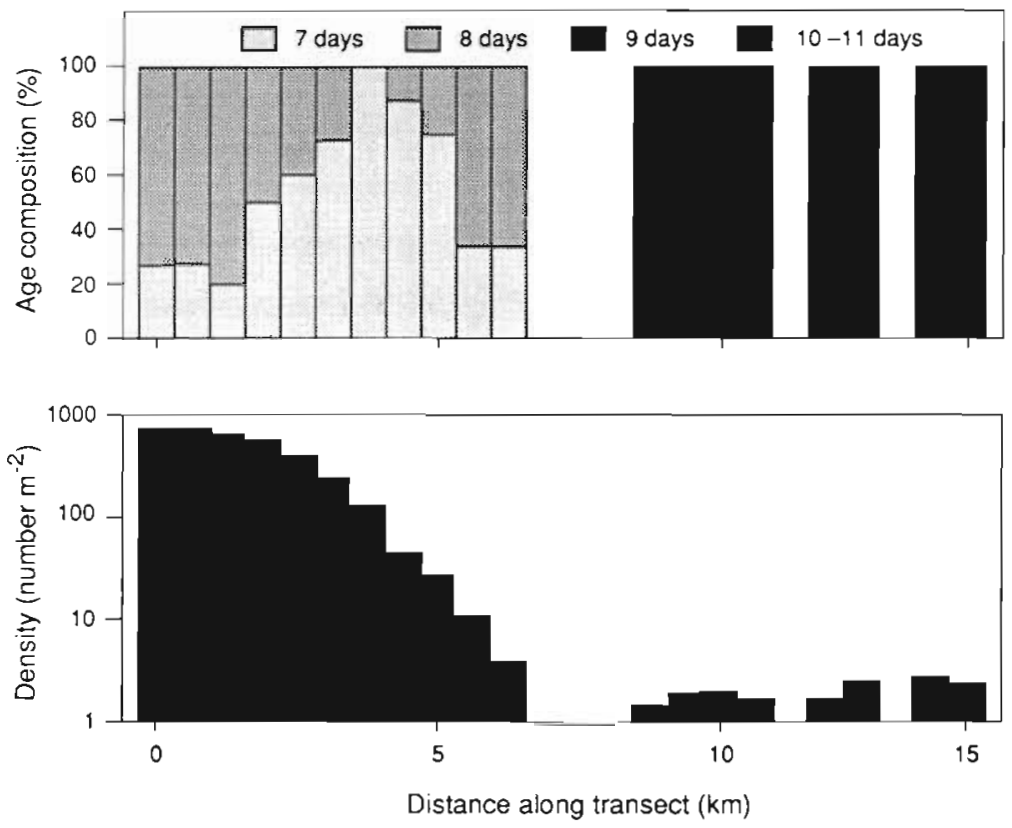

\section{Advection-diffusion-mortality modelling}

were absent at Stns 12 to 14, but occurred in low numbers at many stations throughout the remainder of the transect. T. maccoyii larvae within the patch were 7 to $8 \mathrm{~d}$ old (Fig. 3). All larvae in the smaller patches outside the main patch were older (9 to $11 \mathrm{~d}$ ). Thus the patch consisted of a single cohort of larvae spawned over a $2 \mathrm{~d}$ period, which appeared to be clearly separate from adjacent smaller patches of older larvae. This same cohort dominated random samples taken over the following 5 d (Jenkins \& Davis 1990).

\section{Temporal changes in the distribution and abundance} of larvae

Random sampling of the larval distributions and salinity was conducted during each of the 3 periods, using the drogued buoy as a marker for the patch. The measured distributions showed the centre of the larval patch gradually drifting southward relative to the buoy (Fig. 4). Consequently, by the third period, it appeared that only the northeastern quadrant of the patch was sampled. Peak measured densities declined from 754 larvae $\mathrm{m}^{-2}$ in period 1 to 10 larvae $\mathrm{m}^{-2}$ in period 3 . The estimated total number of larvae contained within the $30 \times 30$ grid $\left(\right.$ area $=2537 \mathrm{~km}^{2}$ ) declined from $3.58 \times$ $10^{10}$ in period 1 to $0.921 \times 10^{10}$ in period 2 , and then to $0.188 \times 10^{10}$ in period 3 . The centre of the patch was located in waters of about $34.84 \%$ at the southern edge of a fresher pool of water intruding from the northeast (Fig. 4). Mixing and southward advection of the fresher water lowered salinities around the sampled region.
Our initial aim was to use the measured salinity distributions to estimate the advection-diffusion parameters, which would then be used in the larval model so only the mortality parameter would need to be estimated. We soon realized that this approach was not appropriate (see 'Discussion') and the physical parameters for the larval distribution had to be obtained simultaneously with the mortality parameter.

Two sets of simulations were run (Table 2): one set for the larval distribution and a second set for the salinity distribution. Temperature data were available for estimating the advection and diffusion parameters but were not used as the air-sea heat fluxes would have had to be calculated and there was insufficient information to do this accurately In each set, model parameters were estimated from the distributions for periods 1 and 2, using period 1 for initialization, and from the distributions for periods 2 and 3, using period 2 for initialization.

The goodness of fit ( $R^{2}$ in Table 2) was clearly much better for the larval simulations $\left(R^{2}>0.8\right)$ than for salinity $\left(\mathrm{R}^{2}<0.4\right)$. The fitted larval distributions were in excellent agreement with observations (Figs. 5 \& 6) and the fitted peak concentrations were within a few percent of the measurements for both periods (Table 2).

All simulations predict that advection during period 1 to 2 was southwestward, but the larvae simulation predicted a much stronger southward component $\left(5.4 \mathrm{~cm} \mathrm{~s}^{-1}\right)$ than did the salinity distributions $(3 \mathrm{~cm}$ $\mathrm{s}^{-1}$ ). All predictions indicate a primarily westward flow 

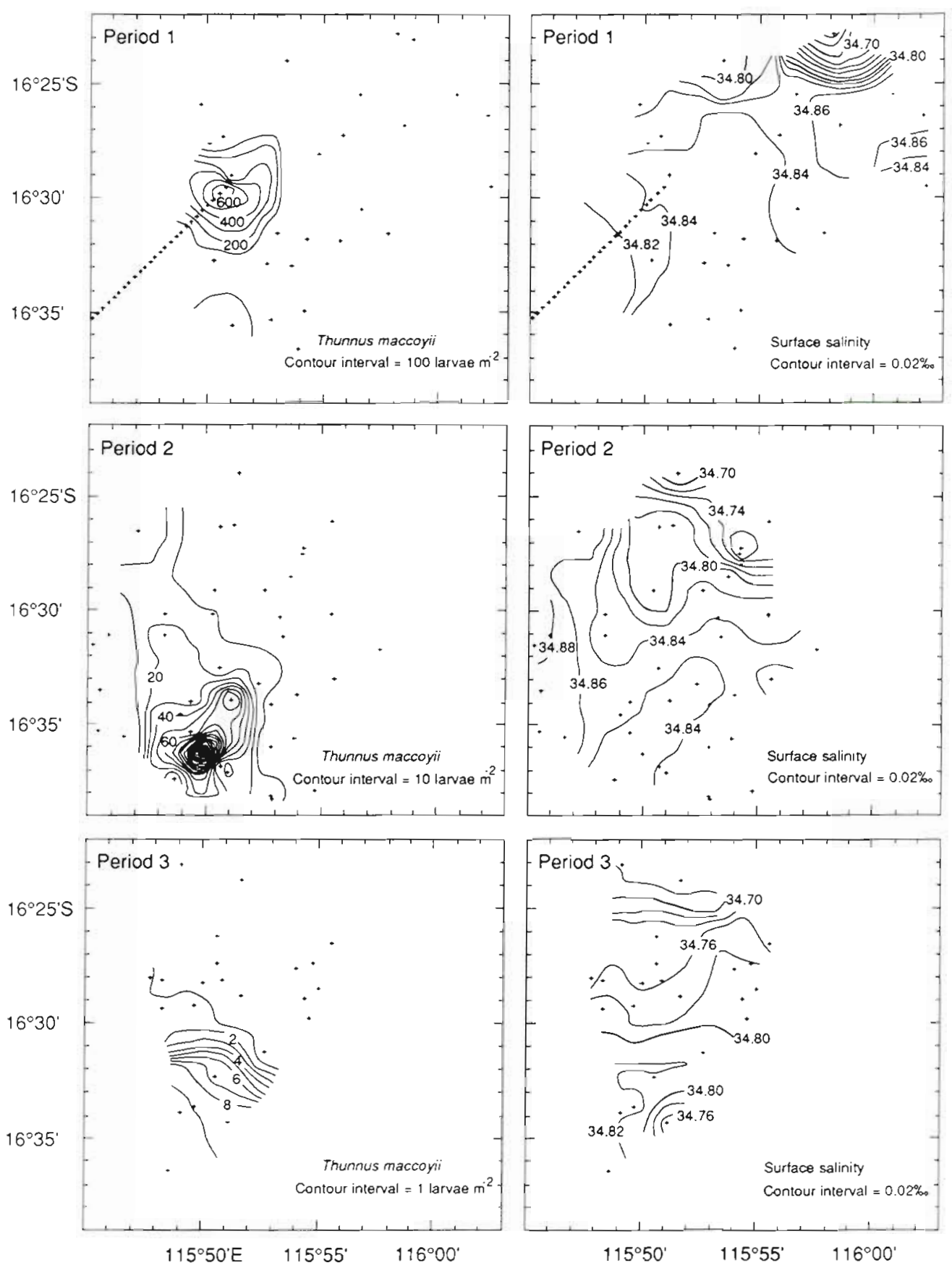

Fig. 4. Thunnus maccoyij. Distribution of larvae and surface salinity from observations made in periods 1 to 3 . + . station positions Contour intervals vary between periods as indicated; values of major contours are given

between periods 2 and 3. Diffusion estimates were much larger for salinity than for larvae and optimal angles were also different.

Instantaneous mortality ( $Z$ ) during periods 1 to 2 was $0.66 \mathrm{~d}^{-1}$ which is equivalent to a daily percentage mortality of $48 \%$. An instantaneous mortality of $0.43 \mathrm{~d}^{-1}$ (daily percentage mortality of $33 \%$ ) was estimated for the period 2 to 3 simulations. For comparison, mortalities were also estimated by examining the decline in the populations within the sampling area (Table 3 ). Both mortality determined by the model $\left(Z=0.66 \mathrm{~d}^{-1}\right)$ and that determined from the decline in the population within the sampling area $\left(Z=0.68 \mathrm{~d}^{-1}\right)$ were in good agreement for periods 1 to 2 . However, there is a clear 
Table 2. Parameters estimated by modelling changes in the distribution of Thunnus maccoyii and salinity between periods. $\phi$ is the angle of the component of the diffusion tensor $K_{l}$, measured anticlockwise from the E-W or $x$-axis. $K_{c}$ is the component at right angles to $K_{l} . \mathrm{R}^{2}$ is the coefficient of determination.

\begin{tabular}{|c|c|c|c|c|c|c|c|c|c|}
\hline \multirow{2}{*}{$\begin{array}{l}\text { Data being } \\
\text { modelled }\end{array}$} & \multicolumn{3}{|c|}{ Diffusion } & \multicolumn{2}{|c|}{ Advection } & \multirow{2}{*}{$\begin{array}{c}\text { Mortality } \\
Z \begin{array}{c}Z \\
\left(d^{-1}\right)\end{array}\end{array}$} & \multirow[t]{2}{*}{$\mathrm{R}^{2}$} & \multirow{2}{*}{$\begin{array}{l}\text { Peak predicted } \\
\text { in next period } \\
\left(\text { no. } \mathrm{m}^{-2}\right)\end{array}$} & \multirow{2}{*}{$\begin{array}{c}\text { Peak observed } \\
\text { in next period } \\
\text { (no. } \mathrm{m}^{-2} \text { ) }\end{array}$} \\
\hline & $\begin{array}{c}K_{c} \\
\left(\mathrm{~m}^{2} \mathrm{~s}^{-1}\right)\end{array}$ & $\begin{array}{c}K_{l} \\
\left(\mathrm{~m}^{2} \mathrm{~s}^{-1}\right)\end{array}$ & $\begin{array}{c}\phi \\
\text { (deg) }\end{array}$ & $\begin{array}{c}V_{x} \\
\left(m s^{-1}\right)\end{array}$ & $\begin{array}{c}V_{y^{\prime}} \\
\left(\mathrm{m} \mathrm{s}^{-1}\right)\end{array}$ & & & & \\
\hline \multicolumn{10}{|l|}{ T maccoyii } \\
\hline Period $1 \rightarrow 2$ & 1.50 & 0.05 & 70.3 & -0.0024 & -0.0536 & 0.66 & 0.93 & 244.5 & 237.1 \\
\hline Period $2 \rightarrow 3$ & 1.02 & 0.30 & 20.0 & -0.0226 & 0.0043 & 0.43 & 0.88 & 10.5 & 10.1 \\
\hline \multicolumn{10}{|l|}{ Salinity } \\
\hline Period $1 \rightarrow 2$ & $5.2^{\cdot}$ & 0.63 & 50.0 & -0.0300 & -0.0291 & - & 0.32 & - & - \\
\hline Period $2 \rightarrow 3$ & 10.0 & 0.10 & 21.6 & -0.0164 & -0.0074 & - & 0.11 & - & - \\
\hline
\end{tabular}

Table 3. Mortality $(Z)$ between periods determined from the advection-diffusion-mortality model and from the estimated population remaining within the $30 \times 30$ grid

\begin{tabular}{|ccc|}
\hline & \multicolumn{2}{c|}{ Mortality, $Z\left(\mathrm{~d}^{-1}\right)$} \\
& $\begin{array}{c}\text { From } \\
\text { model }\end{array}$ & $\begin{array}{c}\text { From estimated } \\
\text { abundance }\end{array}$ \\
\hline Period $1 \rightarrow 2$ & 0.66 & 0.68 \\
Period $2 \rightarrow 3$ & 0.43 & 0.97 \\
\hline
\end{tabular}

discrepancy in mortality estimated by the model $(Z=$ $0.43 \mathrm{~d}^{-1}$ ) and mortality estimated by the decline in the population ( $Z=0.97 \mathrm{~d}^{-1}$ ) for periods 2 to 3 .

Parameters derived from the manual tuning and optimization procedure are not necessarily unique, nor global optima. An indication of the sensitivity of the parameters was calculated from the local Jacobian (gradient of the sum of squares error with respect to each of the parameters) at the chosen optimal point. The Jaco- bian is a finite difference approximation at the approximate solution. Table 4 presents the change required to be made in each parameter so that each change increases the sum of squares error by $25 \%$ of the value at the chosen optima. This percentage is an arbitrary figure which we use only to provide an indication of the parameter sensitivity. In the larval simulations the advective parameters are well estimated, especially the north-south component. Mortality changes required are about $0.1 \mathrm{~d}^{-1}$ but diffusivities changes are larger for periods 2 to 3 . Parameters for the salinity distribution appear to be less well estimated. Diffusivities in particular are more variable than those for the larvae and little confidence can be placed in the diffusivities from salinity, with the possible exception of $K_{l}$ for periods 2 to 3 . The angle of the diffusivity tensor appears to be reasonably well estimated only for the period 1 to 2 larval distribution. Advective changes from salinity are over an order of magnitude greater than those from the larval distribution. Table 4 also gives the sensitivity of the
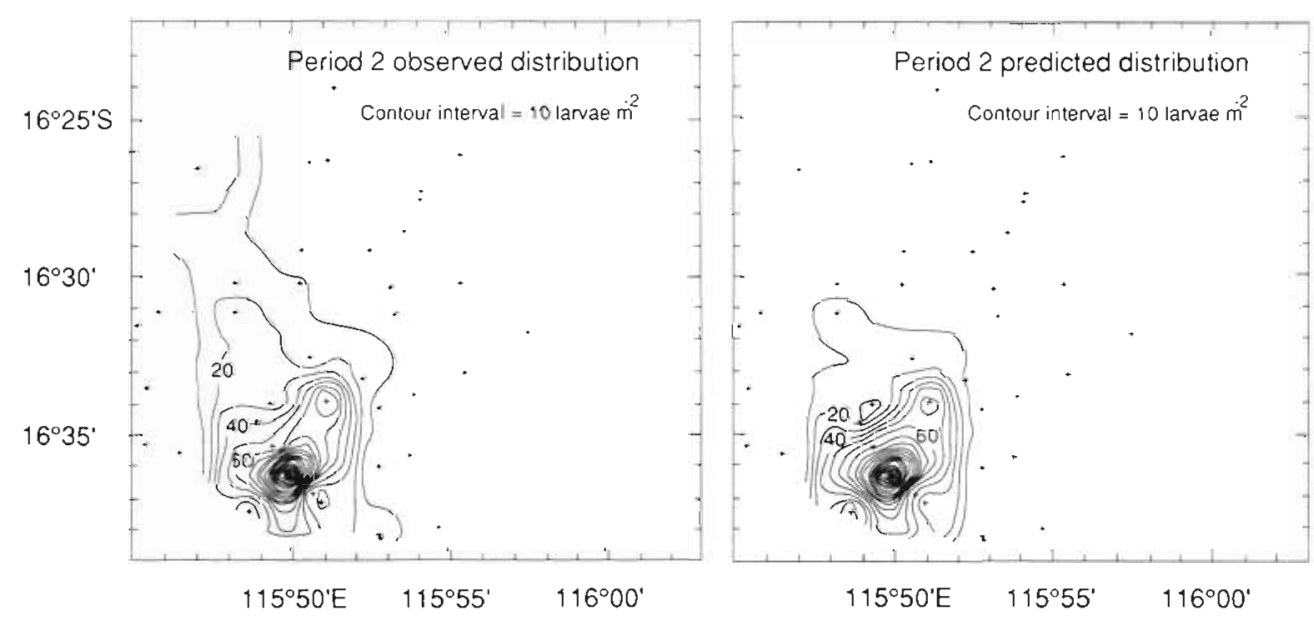

Fig. 5. Thunnus maccoyii. Observed distribution and distribution predicted by the advection-diffusion-mortality model in period 2. The model domain corresponds to the boundary of the plotted distribution 

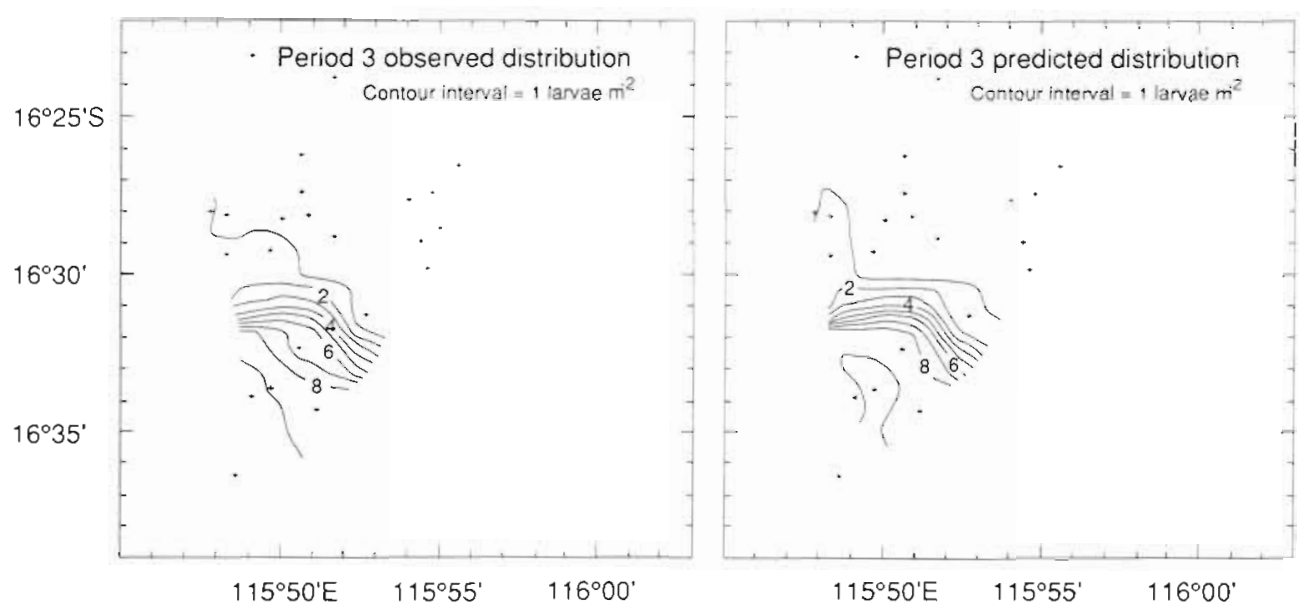

Fig. 6. Thunnus maccoyii. Observed distribution and distribution predicted by the advection-diffusion-mortality model in period 3

Table 4. Parameter changes (absolute values) required to increase the sum of squares error by $25 \%$ from its value at the optima. For each simulation, parameter changes are calculated from the Jacobian, or the gradient of the sum of squares error with respect to each of the parameters, at the optima. The Jacobian is a finite difference approximation at the optimal solution. These changes serve only as an indication of the parameter sensitivity; changing the parameters by the amount shown will not necessarily change the sum of squares error by $25 \%$

\begin{tabular}{|c|c|c|c|c|c|c|}
\hline & $\begin{array}{c}K_{c} \\
\left\{m^{2} s^{-1}\right\}\end{array}$ & $\begin{array}{c}K_{l} \\
\left(\mathrm{~m}^{2} \mathrm{~s}^{-1}\right)\end{array}$ & $\begin{array}{c}\phi \\
\text { (deg) }\end{array}$ & $\begin{array}{c}V_{X} \\
\left(\mathrm{~m} \mathrm{~s}^{-1}\right)\end{array}$ & $\begin{array}{c}V_{y} \\
\left(m s^{-1}\right)\end{array}$ & $\underset{\left(d^{-1}\right)}{Z}$ \\
\hline \multicolumn{7}{|l|}{ Larvae } \\
\hline $1-2$ & 0.53 & 0.35 & 8.4 & 0.0017 & 0.0003 & 0.09 \\
\hline $2-3$ & 0.90 & 4.58 & 51.3 & 0.0012 & 0.0004 & 0.13 \\
\hline \multicolumn{7}{|c|}{ Salinity } \\
\hline $1-2$ & 60.8 & 8.34 & 229.0 & 0.0189 & 0.0153 & - \\
\hline $2-3$ & 246.0 & 0.45 & 86.3 & 0.0233 & 0.0135 & - \\
\hline
\end{tabular}

mortality estimates; the alternate interpretation of the sensitivity analysis is that it provides the change in the mortality parameter required to compensate for a $25 \%$ sum of squares error caused by altering one of the other parameters independently

\section{DISCUSSION}

Dispersion of larvae in the open ocean imposes stringent requirements on sampling to account for the highly dynamic physical processes, the biological processes of mortality and vertical migration, and the measurement uncertainties, particularly the problem of net avoidance; provided of course that one is near a newly spawned patch of larvae in the first place. Our fortuitous discovery of the large patch of newly hatched Thunnus maccoyii larvae presented us with a unique opportunity to study these processes in the open ocean. The principal aim of determining mortality from the change in larval distribution was fraught with difficul- ties, which we attempted to overcome with a predictive model combined with parameter optimization. The original intention of using the buoy to track the centre of the patch, and thereby account for the advective processes, was not successful because of the relative drift of buoy and larval patch

Free-drifting drogues have been used to track aggregations of larvae in order to study such processes as verticai distribution, growth, advection, dispersion and mortality (Dragesund \& Nakken 1971, Hempel \& Schnack 1971, Bjorke 1978, Smith et al. 1978, Conte et al. 1979, Shelton \& Hutchings 1982, Henri et al. 1985, Heath \& MacLachlan 1987. Heath \& Rankine 1988, Röpke 1989). Few of these studies have questioned the efficacy of drogues as Lagrangian reference points. Smith et al. (1978) concluded that their drogue remained within the patch of larvae as there were no significant differences in the size and concentration of larvae over the $3 \mathrm{~d}$ of investigations. The lack of significant change in salinity and temperature and zooplankton composition near the drogue was taken as evidence 
that it followed the drift of anchovy eggs (Shelton \& Hutchings 1982). However, Heath \& Rankine (1988) observed discrepancies between the trajectories of patches of larvae and the drogues intended to track them. These discrepancies were reduced by correcting for wind drag. Fortier \& Leggett (1985) directly measured the movement of their drogue relative to the surrounding water, using recording current meters and temperature and salinity sensors attached to the drogue. Their drogue failed to remain in the original water mass, which they attributed to water drag on the supporting buoy caused by wind-induced acceleration of the top few meters of the water column.

Recent studies on the performance of drifting drogues (Niiler et al. 1987, Bitterman \& Hansen 1989, Chereskin et al. 1989) have established that slippages of a few $\mathrm{cm} \mathrm{s}^{-1}$ can be expected, depending on the drifter design, the prevailing wind, surface gravity waves and the structure of the vertical current shear in the water column. Over a period of a few days, this slippage can amount to a distance comparable to the width of a patch of newly hatched larvae (several kilometers). In our case, even though there was slippage of over $10 \mathrm{~km}$ during the experiment, we were fortunate to have sampled part of the patch in the third period.

Our modelling results show a south to southwestward drift of about $6 \mathrm{~cm} \mathrm{~s}^{-1}$ of the larvae, whereas the buoy initially drifted south but, in response to an intensifying southwesterly wind, reversed and drifted northward towards the end of the third period. This suggests an initial southward current in the surface mixed layer and a later wind-induced northward current in the top few meters causing increased drag on the buoy. There is also a disparity between the predicted initial southward drift of the larvae and the predicted southwestward movement of salinity (Table 2), which may be due to large-scale horizontal velocity shear. Fig. 3 shows that most of the variance in the initial salinity is in the northeast corner, associated with the intruding low salinity water mass, whereas most of the larvae variance is further west and south. Thus, the predictions may be reflecting a spatial variation in current patterns - southwestward flow in the northeast and southward flow further west and south. Our estimates of current vectors are therefore representative only of the currents associated with the central region of the larval patch.

The model's predictions of the principal diffusivity for the larval data $\left(1.02\right.$ to $\left.1.5 \mathrm{~m}^{2} \mathrm{~s}^{-1}\right)$ are within the bounds observed for patches a few kilometers wide, according to Okubo's (1971) diagram. While we have much less confidence in the parameters derived from salinity (Tables $2 \& 4$ ), the large diffusivity observed for salinity $\left(>5 \mathrm{~m}^{2} \mathrm{~s}^{-1}\right)$ may be a reflection of the increased scale over which the salinity anomalies are dispersed or perhaps the enhancement of the horizontal diffusivity by vertical mixing of salinity profiles caused by increasing winds. In any case, the use of diffusivities derived from salinity is clearly not valid for the larval distributions. It should also be noted that we did not take into account the variance in the day/night ratio which would have resulted in increased diffusivities of the larvae. However, we could not find an appropriate method for incorporating this variance in the optimization.

The disparity in mortality estimates for periods 2 to 3 based on the model $\left(0.43 \mathrm{~d}^{-1}\right)$ and the population approach $\left(0.97 \mathrm{~d}^{-1}\right.$ ) (Table 3 ) highlights the necessity for stringent sampling when using the population approach to estimate mortality. In period 3 , only a portion of the total population was sampled (Fig. 3) and hence the mortality from the population approach was overestimated; in this case by more than twice the value from the model. The model was used to fit parameters to period 2 to 3 data to demonstrate the versatility of the method. Nevertheless, we do not consider there was sufficient sampling coverage of the patch during period 3 to place too much reliability on the model's mortality estimate. Thus, the entire spread of larvae must be properly sampled to apply the population approach to mortality. Results from fixed-grid surveys will also be invalid unless the inter-station distances are less than the width of the typical patch. Unless mortality is low, patchiness of larval distribution is likely to persist because mortality tends to counteract the spreading influence of diffusion (Talbot 1977, Koslow et al. 1985).

The model used here improves on the single elliptical spread model used by previous investigators (Munk et al. 1986, Heath \& MacLachlan 1987, Talbot 1977. McGurk 1989). The allure of simplicity offered by the elliptical spread model is, however, at the cost of making the implicit assumptions that spawning is instantaneous and localized at a point, that the advection, diffusion and mortality parameters are constant, and that of course the resulting observed distribution is something like an ellipse. In practice, we have not found a convincing demonstration of an elliptical larval distribution, although the Rhodamine-B dye tracer distributions of Talbot (1977) do resemble ellipses. As Munk et al. (1986) state, it is not always possible to obtain reasonable regressions of ellipses; in many cases, the fitting of ellipses can only be described as gross distortions of observations. Talbot (1977) attempted to account for the irregular distortions to the distributions by calculating the area enclosed between isolines and equating these to equivalent circular areas (Joseph \& Sendner 1958). This technique is only valid for isotropic horizontal diffusion. The method proposed here relaxes the assumptions inherent in the elliptical spread model but with the requirement for measure- 
ments to be made at 2 periods: one for initialization and the other for comparison with predictions. A parameter for the time of origin is not required with our method. As we demonstrate with our estimations, parameters are allowed to, and do, vary with time and there is no requirement for the measured distribution to be elliptical. Parameters are, however, required to be constant between the initialization and prediction periods.

Day/night differences in catches were observed in this patch of Thunnus maccoyii larvae (Davis et al. 1990), which was attributed to avoidance. It is likely that day/night differences in avoidance are only part of the total avoidance problem (Smith \& Richardson 1977). As net avoidance is size-dependent (Barkley 1972, Murphy \& Clutter 1972), the abundance of the larger, presumably older, larvae will be underestimated, as the larvae's ability to avoid the net will have improved over the period that the estimate was made. We have no information on the change in net avoidance ability with size for any tuna species. We can, however, investigate the sensitivity of estimates of $Z$ to changes in the catchability of the larvae, which in the absence of advection and diffusion is given by:

$$
Z=-\frac{1}{t} \ln \left(\frac{\hat{N}_{2}}{\hat{N}_{1} f}\right)
$$

where $\hat{N}_{1}=$ density (no. $\mathrm{m}^{-1}$ ) of larvae observed in period $1 ; \hat{N}_{2}=$ density observed in period $2 ; f=$ ratio of catchabilities of the larvae at the 2 time periods, $t=$ time difference (d) between periods; and the unit of $Z$ is $d^{-1}$.

The relationship between apparent mortality and true mortality has been plotted for changes in catchability of 100 to $50 \%$ for $Z=0.66 \mathrm{~d}^{-1}$ determined between periods 1 and 2 (Fig. 7). It seems unlikely there would be a $50 \%$ reduction in catchability between periods 1 and

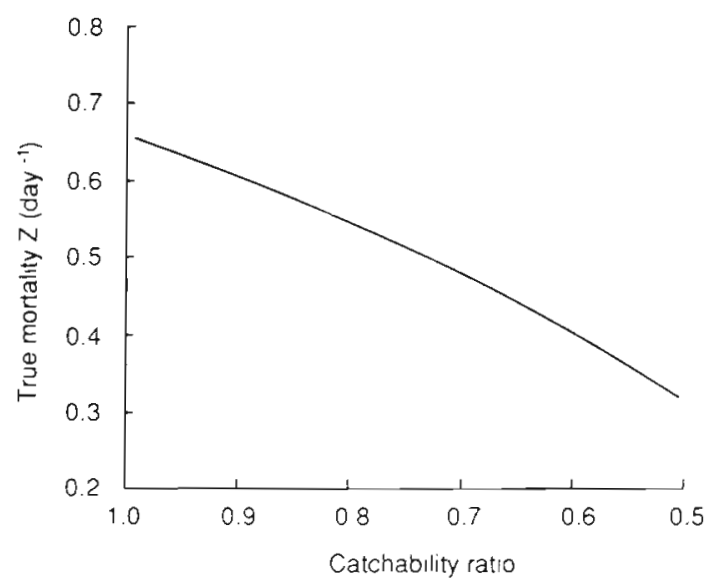

Fig. 7 Thunnus maccoyii. Effect of a change in catchability of larvae between survey periods on estimates of instantaneous mortality (Eq. 4). True mortality where there is no change in catchabulity (catchability ratio $=1.0$ ) is $0.66 \mathrm{~d}^{-1}$
2 , as the larvae would only have grown from about $3.7 \mathrm{~mm}$ to $4.5 \mathrm{~mm}$ in that time (Jenkins \& Davis 1990). If the catchability between periods were reduced by $25 \%$ then $Z$ would still be greater than $0.5 \mathrm{~d}^{-1}$. It is more likely that changes in catchability between periods 2 and 3 would have a greater effect on apparent mortality than between periods 1 and 2 , as the larvae were larger and may have been reaching a size where changes in avoidance ability were more apparent. However, this is not reflected in apparent mortality which was lower between periods 2 and 3 than 2 d earlier. It is nonetheless possible that a decrease in catchability was masked by a true lower mortality.

The value of $Z=0.66 \mathrm{~d}^{-1}$ (a daily survival rate of $52 \% \mathrm{~d}^{-1}$ ) determined between periods 1 and 2 would appear to be our most reliable estimate of the upper limit of instantaneous mortality for Thunnus maccoyii larvae; the lower limit is probably about $0.5 \mathrm{~d}^{-1}$ (a daily survival rate of $60 \% \mathrm{~d}^{-1}$ ). These larvae are past the yolk sac stage, having survived the critical period of transition from endogenous to exogenous feeding (Hjort 1914, May 1974). Their survival rate is much lower than the range of 85 to $97 \% \mathrm{~d}^{-1}$ for marine postyolk-sac larvae reviewed by Dahlberg (1979), although many of those reviewed were clupeiform species with a much longer larval duration: 50 to $130 \mathrm{~d}$ compared to $20 \mathrm{~d}$ in T. maccoyii larvae (Jenkins \& Davis 1990). Our estimate of survival corresponds more closely to estimates of $55 \%$ for Trachurus symmetricus larvae (Hewitt et al. 1985) at about the equivalent stage of development. Young \& Davis (1990) suggested that a significant reduction in prey populations would have been likely near the centre of the patch of $T$. maccoyii larvae, on the basis of larval abundances, larval feeding rates, and prey abundance, and that competition for food would have been possible. Jenkins et al. (in press) demonstrated the density-dependence of larval growth through competition for food. Under conditions of slower growth, cumulative mortality would be higher because the larvae would remain longer within a predatory field (Shepherd \& Cushing 1980). This would not affect the estimation of instantaneous mortality, but it is possible that starvation contributed to the high mortality rate observed in these larvae.

It is useful to consider the origin of this patch of Thunnus maccoyii larvae, as it provides us with information on the spawning of the adults. We estimated that $3.58 \times 10^{10}$ larvae 7 to $8 \mathrm{~d}$ old were in the patch in period 1 . We do not know the cumulative mortality that had occurred from spawning up until $7 \mathrm{~d}$. Richards et al. (1981) and McGowan \& Richards (1986), based on the survival estimates compiled by Dahlberg (1979) for 6 species of marine larvae, used a value of $Z=$ $0.0996 \mathrm{~d}^{-1}$ to estimate cumulative mortality in $9 \mathrm{~d}$ old Thunnus thynnus larvae in the Gulf of Mexico. This 
was equivalent to a $40.8 \%$ survival rate from spawning to $9 \mathrm{~d}$. Our findings suggest that such a high survival rate would be unlikely for T. maccoyii. We estimated survival of 7 to $8 \mathrm{~d}$ larvae over a $2 \mathrm{~d}$ period to be $27 \%$ (37\% if there were a $25 \%$ reduction in catchability). One would not expect the daily mortality rate from spawning up until $7 \mathrm{~d}$ to be less than that observed in $7 \mathrm{~d}$ old larvae as there is evidence that mortality rates decline exponentially with increasing size (Peterson \& Wroblewski 1984, McGurk 1986). If instantaneous mortality averaged over the entire period from spawning to $7 \mathrm{~d}$ was $Z=0.66 \mathrm{~d}^{-1}$ then survival would only be about $1 \%$. Our estimate of the number of eggs spawned over the $2 \mathrm{~d}$ using $Z=0.66 \mathrm{~d}^{-1}$ is $3.63 \times 10^{12}$ eggs. Kikawa (1964) estimated fecundity to be $15 \times 10^{6}$ eggs in a $158 \mathrm{~cm}(80 \mathrm{~kg})$ fish. The size range of adults caught on the spawning ground has been reported to be 135 to $180 \mathrm{~cm}$ with a sex ratio of 1.2 males : 1 female (Robins 1963). Assuming total spawning and that the average size of fish was $158 \mathrm{~cm}$, then ca $5 \times 10^{5}$ fish $(40000 \mathrm{t}$ ) were involved in the spawning event that generated the patch. While this estimate is very crude and subject to unassessed error it seems very high, as the parental biomass is considered to be 120000 to $240000 \mathrm{t}$ (W. Hearn pers. comm. 1990). The mortality rate observed during this study may have been higher than normal due to factors such as starvation, as discussed previously. Using this value to estimate cumulative mortality would overestimate the number of eggs produced. Alternatively, parental biomass estimates may be too low. Even if cumulative mortality was half this value $\left(Z=0.33 \mathrm{~d}^{-1}\right)$ then $5.3 \times 10^{4}$ fish $(4200 \mathrm{t})$ were involved in this spawring event, indicating that spawning in $T$. maccoyii may take place in very large schools. Acoustic surveys of the spawning grounds usually detect large tuna (species unknown) as individual marks or in small schools rarely exceeding 200 individuals (Yukinawa \& Miyabe 1984). No schools of the magnitude estimated in this study have been reported, so it seems likely that adults may come together briefly for spawning and then disperse. It is not known whether this major spawning episode was unique or whether similar spawning events occurred in a number of places within the spawning area, or whether spawning on this scale occurred at other times during a protracted spawning period, as sampling has not yet been carried out at the appropriate temporal and spatial scales. Even if such sampling can be carried out it is imperative that proper account be taken of advection and diffusion in calculations of mortality. The standard paradigm based on a single elliptical model is unacceptable, especially in the open ocean where the physical processes in the near-surface layers change rapidly and sampling is difficult. The method proposed here is an attempt to provide improved estimates of mortality.
Acknowledgements. We thank the Master and crew of FRV 'Soela' and CSIRO personnel, particularly J. L. May, D. W. Rimmer and J. W. Young, who assisted in the field work. $O$. Augustine sorted many samples and determined the age of the larvae. P. Bonham sorted and identified the species of tuna larvae. G. R. Cresswell provided the satellite-tracked buoys and drift data. We are grateful to A. Caton, F. R. Harden Jones J. W Horwood, J. A. Koslow and J. S. Parslow for suggesting improvements to the manuscript.

\section{LITERATURE CITED}

Barkley, R. A. (1972). Selectivity of towed-net samplers. Fish. Bull. U.S. 70: 799-820

Bitterman, D. S., Hansen, D. V. (1989). Direct measurements of current shear in the tropical Pacific Ocean and its effect on drift buoy performance. J. Atmos. Oceanic Technol. 6 (2): $274-279$

Bjorke, H. (1978). Food and feeding of young herring larvae of Norwegian spring spawners. FiskDir. Skr. Ser. Havunders. 16: $405-421$

Caton, A., Majkowski, J. (1987). Warning issued on global catch limits. Aust. Fish. 46: 22-24

Chereskin, T K., Niiler, P. P., Poulain, P. M. (1989). A numerical study of the effects of upper-ocean shear on flexible drogued drifters. J. Atmos. Oceanic Technol. 6 (2): $243-253$

Chenoweth, S. B., Libby, D. A., Stephenson, R. L., Power, M. J. (1989). Origin and dispersion of larval herring (Clupea harengus) in coastal waters of eastern Maine and southwestern New Brunswick. Can. J. Fish. Aquat. Sci. 46: $624-632$

Conte, M. H., Otto, R. G., Miller, P. E. (1979). Short-term variability in surface catches of ichthyoplankton in the upper Chesapeake Bay. Estuar. coast. mar. Sci. 8: 511-522

Cresswell, G. R., Richardson, G. T., Wood, J. E., Watts, R. (1978). The CSIRO satellite-tracked 'torpedo' buoy. CSIRO Aust. Div. Fish. Oceanogr. Rep. 82: 1-13

Cushing, D. H. (1975). Marine ecology and fisheries. Cambridge University Press, Cambridge

Dahlberg, M. D. (1979). A review of survival rates of fish eggs and larvae in relation to impact assessments. Mar Fish. Rev. 41: 1-12

Davis, T. L. O. Clementson, L. A. (1989). Data report on the vertical and horizontal distribution of tuna larvae in the East Indian Ocean, January-February 1987 CSIRO Mar. Lab. Rep. 206: 1-39

Davis, T. L. O., Jenkins, G. P., Yukinawa, M., Nishikawa, Y. (1989). Tuna larvae abundance: comparative estimates from concurrent Japanese and Australian sampling programs. Fish. Bull. U.S. 87 976-981

Davis, I L. O., Jenkins, G. P., Young, J. W. (1990a). Diel patterns of vertical distribution in larvae of southern bluefin (Thunnus maccoyii), and other tuna in the East Indian Ocean. Mar. Ecol. Prog. Ser 59: 63-74

Davis, T L. O., Jenkins, G. P., Young, J. W. (1990b). Patterns of horizontal distribution in larvae of southern bluefin (Thunnus maccoyii) and other tuna in the Indian Ocean. J. Plankton Res. 12: 1295-1314

Dragesund, O., Nakken, O. (1971). Mortality of herring during the early larval stage in 1967. Rapp. P.-v. Réun. Cons. int. Explor. Mer 160: 142-146

Fortier, L., Leggett, W. C. (1985). A drift study of larval fish survival. Mar. Ecol. Prog. Ser 25: 245-257

Harding, D., Talbot, J. W (1973). Recent studies on the eggs 
and larvae of the plaice (Pleuronectes platessa L.) in the Southern Bight. Rapp. P.-v. Réun. Cons. int Explor. Mer 164: 261-269

Heath, M. MacLachlan, P. (1987). Dispersion and mortality of yolk-sac herring (Clupea harengus L.) larvae from a spawning ground to the west of the Outer Hebrides. J. Plankton Res. 9: 613-630

Heath, M., Rankine, P. (1988). Growth and advection of larval herring (Clupea harengus L.) in the vicinity of the Orkney Isles. Estuar coast. Shelf Sci. 27: $547-565$

Hempel, G., Schnack, D. (1971). Larval abundance of spawning grounds of Banks and Downs herring. Rapp. P.-v. Réun. Cons. int. Explor. Mer 160: 94-98

Henderson, P. A., Whitehouse, J. W., Cartwright, G. H. (1984). The growth and mortality of larval herring. Clupea harengus L., in the River Blackwater Estuary, 1978-1980. J. Fish. Biol. 24: 613-622

Henri, M., Dodson, J. J., Powles, H. (1985). Spatial configurations of young herring (Clupea harengus harengus) larvae in the St. Lawrence estuary: importance of biological and physical factors. Can. J. Fish. Aquat. Sci. 42 (Suppl. 1): 91-104

Hewitt, R. P., Theilacker, G. H., Lo, N. C. H. (1985). Causes of mortality in young jack mackerel. Mar. Ecol. Prog. Ser. 26: $1-10$

Hill, A. E. (1990). Pelagic dispersal of Norway lobster Nephrops norvegicus larvae examined using an advection-diffusion-mortality model. Mar. Ecol. Prog. Ser. 64: 217-226

Hjort, J. (1914). Fluctuations in the great fisheries of northern Europe viewed in the light of biological research. Rapp. P.-v. Réun. Cons. int. Explor Mer 20: 1-228

Incze, L. S., Kendall, A. W. Jr, Schumacher, J. D., Reed, R. K. (1989). Interactions of a mesoscale patch of larval fish (Theragra chalcogramma) with the Alaska coastal current. Cont. Shelf Res. 9: 269-284

Jenkins, G. P., Davis, T L. O. (1990). Age, growth rate, and growth trajectory of southern bluefin tuna, Thunnus maccoyii, larvae determined from otolith microstructure. Mar. Ecol. Prog. Ser. 63: 93-104

Jenkins, G. P., Young, J. W., Davis, T L. O. (in press). Densitydependence of larval growth of a marine fish, the southern bluefin tuna, Thunnus maccoyii. Can. J. Fish. Aquat. Sci.

Joseph, J., Sendner, H. (1985). Über die horizontale Diffusion im Meere. Dt. hydrogr. Z. $11 \quad 49-77$

Kikawa, S. (1964). Estımated number of eggs spawned out of the ovaries of an indomaguro (Thunnus maccoyii?). Rep. Nankai Reg. Fish. Res. Lab. 20: 27-35

Kiørboe, T., Munk, P., Richardson, K., Christensen, V., Paulsen, H. (1988). Plankton dynamics and larval herring growth, drift and survival in a frontal area. Mar. Ecol. Prog. Ser 44: 205-219

Klawe, W. L. (1963). Observations on the spawning of four species of tuna (Neothunnus macropterus, Katsuwonus pelamis, Auxis thazard, and Euthynnus lineatus) in the eastern Pacific Ocean, based on the distribution of their larvae and juveniles. Inter-Am. Trop. Tuna Comm. Bull. 6 : $449-540$

Koslow, J. A., Brault, S., Dugas, J., Page, F. (1985). Anatomy of an apparent year-class failure: the early life history of the 1983 Browns Bank haddock Melanogrammus aeglefinus Trans. Am. Fish. Soc. 114: 478-489

Leak, J. C., Houde, E. D. (1987). Cohort growth and survival of bay anchovy Anchoa mitchilli larrate in Biscayne Bay, Florida. Mar Ecol. Prog. Ser 37: 109-122

May, R. C. (1974). Larval mortality in marine fishes and the critical period concept. In: Blaxter, J. H. S. (ed.) The early life history of fish. Springer-Verlag, Berlin, p. 3-19
McGowan, M. F., Richards, W. J. (1986). Distribution and abundance of bluefin tuna (Thunnus thynnus) larvae in the Gulf of Mexico in 1982 and 1983 with estimates of the biomass and population size of the spawning stock for 1977, 1978 and 1981-1983. Int. Comm. Conserv. Atlant. Tuna, Coll. Vol. Sci. Pap. 24: 182-195

McGurk, M. D. (1986). Natural mortality of marine pelagic fish eggs and larvae: role of spatial patchiness. Mar. Ecol. Prog. Ser 34: 227-242

McGurk, M. D. (1989). Advection, diffusion and mortality of Pacific herring larvae Clupea harengus pallasi in Bamfield Inlet, British Columbia. Mar. Ecol. Prog. Ser. 51: 1-18

Munk, P., Christensen, V., Paulsen, H. (1986). Studies of a larval herring (Clupea harengus L.) patch in the Buchan area. II. Growth, mortality and drift of larvae. Dana 6 : $11-24$

Murphy, G. I., Clutter, R. I. (1972). Sampling anchovy larvae with a plankton purse seine. Fish. Bull. U.S. 70: 789-798

Niiler, P. P., Davis, R. E., White, H. J. (1987). Water-following characteristics of a mixed-layer drifter. Deep Sea Res. 34: $1867-1881$

Nishikawa, Y (1985). Identification for larvae of three species of genus Thunnus by melanophore patterns. Bull. Far Seas Fish. Res. Lab. 22: 119-130

Nishikawa, Y., Honma, M., Ueyanagi, S., Kikawa, S. (1985) Average distribution of larvae of oceanic species of scombrid fishes, 1956-1981 Far Seas Fish. Res. Lab. S. Ser 12

Nishikawa, Y., Rimmer, D. W. (1987). Identification of larval tunas, billfishes and other scombroid fishes (Suborder Scombroidei): an illustrated guide. CSIRO Mar. Lab. Rep. 186: $1-20$

Okubo, A. (1971). Oceanic diffusion diagrams. Deep Sea Res. 18: $789-802$

Peterson, I., Wroblewski, J. S. (1984). Mortality rate of fishes in the pelagic ecosystem. Can. J. Fish. Aquat. Sci. 41 $1117-1120$

Richards, W. J., Potthoff, T (1980). Distribution and abundance of bluefin tuna larvae in the Gulf of Mexico in 1977 and 1978. Int. Comm. Conserv. Atlant. Tuna, Coll. Vol. Sci. Pap. 9: 433-441

Richards, W. J., Potthoff, T., Houde, E. D. (1981). Abundance of bluefin tund larvae and estimates of spawning stock sizes in the Gulf of Mexico in 1977 and 1978. Int. Comm. Conserv. Atlant. Tuna, Coll. Vol. Sci. Pap. 15: 273-277

Richards, W. J., Simmons, D. C. (1971). Distribution of tuna larvae (Pisces, Scombridae) in the northwestern Gulf of Guinea and off Sierra Leone. Fish. Bull. U.S. 69: 555-568

Robins, J. P. (1963). Synopsis of biological data on bluefin tuna, Thunnus maccoyii (Castlenau) 1972. FAO Fish. Rep. 6: $562-587$

Röpke. A. (1989). Day/night differences in determination of growth rate of mackerel Scomber scombrus larvae during a patch-study in the Celtic Sea Mar. Biol. 102: 439-443

Rothschild, B. J., Osborn, I R., Dickey, T D., Farmer, D. M. (1989). The physical basis for recruitment variability in fish populations. J. Cons. int. Explor Mer 45: 136-145

Saville, A., Schnack, D. (1981). Some thoughts on the current status of studies of fish egg and larval distribution and abundance Rapp. P.-v. Réun. Cons. int. Explor Mer 178: 153-157

Shelton, P. A., Hutchings, L. (1982). Transport of anchovy Engraulis capensis Gilchrist, eggs and early larvae by a frontal jet current. J. Cons. int. Explor Mer 40: 185-198

Shepherd, J. G., Cushing, D. H. (1980). A mechanism for density-dependent survival of larval fish as the basis of a stock-recruitment relationship. J. Cons. int. Explor Mer 39: $160-167$ 
Shingu, C. (1981). Ecology and stock of southern bluefin tuna. CSIRO Div. Fish. Oceanogr Rep. 131

Smith, P. E., Richardson, S. L. (1977). Standard techniques for pelagic fish egg and larva surveys. FAO Fish. Tech. Pap. 175

Smıth, W. G., Sibunka, J. D., Wells, A. (1978). Diel movements of larval yellowtail flounder, Limanda ferrugina, determined from discrete depth sampling. Fish. Bull. U.S. 60: $231-255$

Talbot, J. W. (1977). The dispersal of plaice eggs and larvae in the Southern Bight of the North Sea. J. Cons. int. Explor Mer 37.221-248

Young, J. W., Davis, T L. O. (1990). Feeding ecology of larvae of southern bluefin, albacore and skipjack tunas (Pisces:

This article was submitted to the editor
Scombridae) in the eastern Indian Ocean. Mar Ecol. Prog. Ser $61 \cdot 17-29$

Yukinawa, M. (1987). Report on 1986 research cruise of the R/ $\checkmark$ Shoyo-Maru. Distribution of tunas and billfishes larvae and oceanographic observation in the eastern Indian Ocean January-March, 1987 Rep. Res. Div., Fish Agency Jpn. $61 \quad 1-100$

Yukinawa, M., Miyabe, N. (1984). Report on 1983 research cruise of the R/V Shoyo-Maru. Distribution of tunas and billfishes and their larvae in the eastern Indian Ocean October-December, 1983. Rep. Res. Div., Fish. Agency Jpn. 58: 1-103

Wade, C. B. (1951). Larvae of tuna and tuna-like fishes from Philippine waters. Fish. Bull. U.S. 51: 445-485

Manuscript first received: November 12, 1990

Revised version accepted: March 20, 1991 